\title{
СОЦІАЛЬНИЙ ДОСВІД ФОРМУВАННЯ ІННОВАЦІЙНОЇ КОНФІГУРАЦІЇ СУЧАСНИХ ЗНАНЬ
}

Актуальність теми дослідження. Сьогодні вчені повертаються до думки про пріоритетне значення науки в суспільстві, формується свідоме прагнення людства до створення більш гуманної конфрігурації його соціальних відносин.

Постановка проблеми. Інноваційна конфрігурація системи знань повинна мати нетрадиційний децентралізований характер з обов'язковим урахуванням особливостей національно-смислового поля та типу культури відповідного суспільного виробництва.

Аналіз останніх досліджень і публікацій. Джерельну базу дослідження складають концептуальні здобутки таких знаних авторів, як Л. Барроуз, П. Бурдье, Д. Белл, М. Гайдеггер, П. Друкер, Е. Дюркгейм, С. Жижек, Ж.-Ф. Ліотар, Н. Луман, Т. Парсонс, О. Тофрфлер, У. Еко та багато інших дослідників. Історіографрічним базовим джерелом дослідження стали праці таких вітчизняних науковців, як В. Андрущенко, Л. Вознюк, Е. Герасимова, С. Клепко, С. Куцепал, В. Кушерець, М. Муляр, Д. Свириденко, С. Терепищий та ін.

Виділення недосліджених частин загальної проблеми. Можемо стверджувати, що процес осмислення природи та сутності інноваційних процесів знаходиться у постійному динамічному стані, тому незважаючи на потужні розвідки, проведені відомими вітчизняними $i$ зарубіжними вченими, низка питань залишається без відповіді.

Постановка завдання. Метою дослідження нашої публікації є аналіз соціального досвіду формування інноваційної конфрігурації сучасних знань.

Виклад основного матеріалу. Нова конфрігурація сучасної системи знань - це злагоджене поєднання можливостей, компетенцій, як матеріальних, так і невидимих ресурсів, цінностей та прагнень ефективної результативності, яких вона намагається досягти в майбутньому за рахунок синергійних конфігурацій.

Висновки. Проаналізувавши конфрігурований синергетичний ефрект інноваційного процесу формування сучасної системи знань в Україні як складний соціальний акт, було представлено механізм взаємодії багатьох фракторів з обов'язковим урахуванням особливостей національно-смислового поля та типу культури відповідного суспільного виробництва та можливості отримання суспільного результату від його практичного застосування.

Ключові слова: знання; людина; суспільство, наука; конфрігурація сучасних знань; компетенції; інноваційні процеси; соціальний досвід.

M. A. Lukashuk, Postgraduate student

\section{SOCIAL EXPERIENCE OF FORMING AN INNOVATIVE CONFIGURATION OF MODERN KNOWLEDGE}

Urgency of the research. Today scholars are returning to the idea of the priority importance of science in society, a conscious desire of mankind to create a more humane configuration of its social relations is being formed.

Target setting. The innovative configuration of the knowledge system should have an unconventional decentralized nature with the obligatory consideration of the peculiarities of the national semantic field and the type of culture.

Actual scientific researches and issues analysis. The source study base of the research is made up of conceptual developments of such famous authors as L. Burrows, P. Bourdieu, D. Bell, M. Heidegger, P. Drucker, E. Durkheim, S. Zizek, J.-F. Lyotard, N. Luhmann, T. Parsons, O. Toffler, W. Eco and many other researchers. The works of such domestic scientists as V. Andrushchenko, L. Voznyuk, E. Gerasimova, S. Klepko, S. Kutsepal, V. Kusherets, M. Mulyar, D. Sviridenko, S. Terepischiy and others became the historiographic literature of the study.

Uninvestigated parts of general matters defining. We can state that the process of comprehending the nature and meaning of innovative processes is in a constant dynamic state, therefore, despite the large-scale nature of the research carried out by famous domestic and foreign scientists, a set of questions remains unanswered. 
The research objective is to analyze the social experience of the formation of an innovative configuration of modern knowledge.

The statement of basic materials. The new configuration of the modern knowledge system is a coordinated combination of opportunities, competencies, both material and invisible resources, values and aspirations for effective performance, which can be achieved in the future due to synergistic configurations.

Conclusions. Having analyzed the configured synergistic effect of the innovative process of forming a modern knowledge system in Ukraine, as a complex social act that covers the analysis of many key competencies, taking into account the features of the national semantic field and the type of culture of the corresponding social production, as well as the possibility of obtaining effective social result from its practical application, the mechanism of their interaction was presented.

Keywords: knowledge; person; society; science; configuration of modern knowledge; competencies; innovation processes; social experience.

DOI: 10.25140/2412-1185-2019-2(14)-100-107

Актуальність теми дослідження. Сьогодні, як і в епоху Просвітництва, вчені повертаються до думки про пріоритетне значення науки в суспільстві, формується свідоме прагнення людства до створення більш гуманної конфігурації його соціальних відносин. Подібна установка має загальновизнаний характер, а розуміння самої категорії «розвиток» дотепер не має однозначного визначення. Нам імпонує теоретичний підхід, який був запропонований С. Кримським: «розвиток - це насамперед внутрішньо детермінований процес якісного перетворення певних об'єктів аж до виходу до іншого статусу їх існування (інобуття): процес який характеризується кумулятивністю (здатністю збагачення за рахунок вбирання переробленого змісту попередніх фраз процесу), наростанням ступенів свободи та індивідуалізації його (процесу) елементів та розширенням диференціації самого предмету змін відповідно його включенню в більш універсальні зв'язки цілого (тотальності)» [1, с. 201].

Отже, дотепер потребує додаткового аналізу проблематика реалізації постійного суспільного вибору шляхів та способів руху, характеристики соцієтального простору процесу вітчизняного поступу та перетворень, зміна статусу такого важливого соціально-економічного фактору, як людський капітал, з'ясування механізму та моделей функціонування капіталу знань з точки зору практичної діяльності, тому можемо стверджувати, що єдиного наукового визначення стосовно заявлених питань немає. Ураховуючи актуальність та недостатню опрацьованість зазначеної тематики, ми обрали її як предмет дослідження у наший публікації.

Постановка проблеми. Сучасну дослідницьку ситуацію можна визначити як динамічну складність, тому інноваційна конфігурація системи знань повинна мати нетрадиційний децентралізований характер 3 обов'язковим урахуванням особливостей національносмислового поля та типу культури відповідного суспільного виробництва.

Аналіз останніх досліджень і публікацій. Джерельну базу дослідження складають твори, які розкривають сутність та динаміку сучасного інформаційно-високотехнологічного процесу та роль соціальних наук у конструюванні суспільства знань. Поняттям «інновація» позначають нововведення, а широкий спектр питань, що об'єднує проблематика інновацій та теорії «людського капіталу», зумовлює широкий джерельний базис дослідження, у якому враховувалися концептуальні здобутки таких знаних авторів, як Л. Барроуз, П. Бурдье, Д. Белл, М. Гайдеггер, М. Гіббонс, Д. Д'юї, П. Друкер, Е. Дюркгейм, С. Жижек, Е. Левинас, Ж.-Ф. Ліотар, Н. Луман, Т. Парсонс, О. Тофффлер, М. Фуко, Й. Шумпетер, У. Еко та багато інших дослідників. Особливу увагу було звернено на публікації, у яких розкривається унікальність потенціалу соціальної синергетики як оптимальної можливості досягнення ефективного результату створення нової організаційної системи знань, класичним прикладом є ідеї І. Пригожина та І. Стінгерс, а також роботи таких дослідників як Л. Бевзенко, В. Буданова, В. Додонової та багатьох інших. Історіографічним базовим джерелом дослідження стали праці таких вітчизняних науковців, як В. Андрущенко, Л. Вознюк, Е. Герасимова, С. Клепко, С. Куцепал, В. Кушерець, М. Муляр, Д. Свириденко, С. Терепищий та ін. Заслуговують на увагу такі монографічні дослідження вітчизняних фахівців як роботи В. Отрешко «Гуманітарна стратегія інноваційного розвитку українського суспільства. Політологічний концепт», Н. Поліщук «Духовність молоді 
перед викликами інформаційно-високотехнологічного прогресу», О. Старовойт «Філософські засади формування інноваційної культури» та декілька інших праць. Але сьогодні залишається ціла низка проблем, на які в наявній літературі достатньо обґрунтованих відповідей немає.

Виділення недосліджених частин загальної проблеми. Можемо стверджувати, що процес осмислення природи та сутності інноваційних процесів знаходиться у постійному динамічному стані, тому незважаючи на потужні розвідки, проведені відомими вітчизняними і зарубіжними вченими, низка питань залишається без відповіді.

Постановка завдання. Метою дослідження нашої публікації $€$ аналіз соціального досвіду формування інноваційної конфігурації сучасних знань.

Виклад основного матеріалу. Сучасну дослідницьку ситуацію можна визначити як динамічну складність, тому інноваційна конфігурація системи знань повинна мати нетрадиційний децентралізований характер з обов'язковим урахуванням особливостей національно-смислового поля та типу культури відповідного суспільного виробництва. Специфріка інноваційного контексту повинна забезпечити процес у формування дослідницької стратегії проєкту в будь-якій науковій галузі швидке ефективне реагування на зміни в складному внутрішньому та непрогнозованому зовнішньому середовищі. Інноваційні проєкти, відіграючи роль першого етапу в процесі соціалізації результатів дослідження та їхнього визнання. Такі своєрідні інноваційно-дослідні програми визначають методологічні та процедурні пріоритети між окремими науковими проєктами певних сфер діяльності, а також надають можливість здійснювати дослідження масштабного національного характеру з подальшим програмуванням. Можемо зазначити, що інноваційні компетенції сучасної системи знань складаються 3 інтегральної інформаційно-технологічної моделі дослідження, науково-педагогічних технологій навчання, особистісно-професійної компетентності самого фрахівця та новітніх механізмів, методів і засобів системи управління сучасної науково-дослідницької сфери.

Своєрідний менеджмент сучасної системи знань формує поле проблемних питань навколо теорії капіталу знання, закладеної в основу його функціонування. Ефективний результат створення нової організаційної системи знань зростає, якщо синергійний ефект від конфігурованого цілого більший, ніж ефект від поєднання певної суми елементів або в результаті створення відповідної комбінації одночасно функціонуючих окремо, але взаємопов'язаних складників системи. Зрозуміло, що в контексті дослідження принцип синергізму слід розглядати як методику та методологію моделювання стратегії науководослідної та освітньої практики. Крім того, варто зазначити про те, що якими б потенційно прогресивними не були його можливості та результати синергійного ефекту, він не може виявлятися сам по собі. Такий ефект потрібно свідомо планувати й організовувати, тому першочерговим завданням управління $€$ виявлення внутрішнього потенціалу самої системи та її ресурсної бази, результати дослідження якої й стануть джерелом отримання синергетичної переваги. «Нововведення $€$ нормальним і безумовним станом сучасної інноваційно орієнтованої освіти. Вони не просто приносять користь окремим суб'єктам навчання і виховання, але й здійснюють важливу педагогічну функцію - привчають людину до реальності сучасного світу, в якому зміна і новизна є онтологічними ознаками, без яких не уявляється цивілізаційне буття XXI століття. I навчаючись постійно прагнути до нового, адекватно приймати новизну та самими створювати нововведення, суб'єкти освіти виступають як суб'єкти інновації. Практична реалізація суб'єктами інноваційної діяльності виражається в здійсненні інноваційних процесів. Інноваційний характер освітньої діяльності виявляється тоді, коли суб'єкти освіти будь-яким чином взаємодіють 3 педагогічним нововведенням: освоюють, проектують, розробляють, апробують, упроваджують. Інноваційні аспекти виявляються й у тих випадках, коли елементи новизни присутні в діяльності суб'єктів освіти» [2, с. 38].

Отже, новизна як така формує умови та виступає головним індикатором інноваційного процесу в освіті. При цьому така новизна може носити різний характер. Вона може виявлятися в розробці нових підручників чи методичних матеріалів, застосуванні нових організаційних чи виховних форм, впровадженні новітніх інформаційних технологій, що роблять освітній процес доступнішим і зручнішим тощо.

В експертному середовищі існує також позиція, що освітня інновація - це не просто привнесення в структуру навчально-виховного процесу якоїсь новизни, але насамперед вдосконалення, зміна культурного простору освіти. Іншими словами, новизна має бути 
орієнтованою на реальну якісну зміну навчально-виховного процесу, який завдяки її впровадженню стане ефективнішим, доступнішим, більше орієнтованим на конкретні потреби визначених суб'єктів освіти. У той самий час, навіть не визнаючи сутнісний статус новизни як базового інноваційного компонента, не можна заперечувати того, що саме новизна є головним індикатором інноваційного процесу в освіті. Найпершим критерієм інноваційності тієї чи іншої дії в навчально-виховному процесі $€$ те, що ця дія певним чином відрізняється від традиційних еталонів, а значить, несе елемент оновлення, новизни та творчого нового впровадження.

На системному рівні управління освітою надзвичайно важливим є визначення спрямованості новизни, критеріїв її оцінювання, якісних характеристик, що визначатимуть доцільність чи неприйнятність прийняття конкретних нововведень. Іншими словами, новизна в освіті не може бути стихійною. Нововведення мають обґрунтовуватися, як на науково-парадигмальному і педагогічно-практичному рівні, так і на рівні загальнонаціональної системи управління українською освітою. Освітні (педагогічні) інновації характеризуються новизною, спрямованою, як зазначається у Білій книзі української освіти, «на якісне покращання освітнього процесу і відображаються в удосконалених або нових освітніх системах (дидактичній, виховній, управлінській), складових освітнього процесу (меті, змісті, структурі, формах, методах, засобах, результатах), освітніх технологіях (дидактичних, виховних, управлінських), наукових та науковометодичних розробках, інформаційно-комунікаційній техніці для закладів і установ освіти, а також нормативно-правових документах, що регламентують діяльність навчальних закладів і установ освіти та їх відносини з іншими інституціями» [3].

Отже, новизна $є$ актуальним феноменом буквально в усіх можливих вимірах функціонування національної системи освіти. Багато в чому це зумовлено ще й тим, що за останні два десятиліття в Україні не здійснено багато з необхідних реформ. Сьогодні наша система освіти продовжує перебувати в кризово-трансформаційному стані, що й зумовлює високу актуальність дослідження феномену новизни як головного індикатора інноваційних процесів в освіті. При цьому неможливо обмежити новизну, що привноситься завдяки інновації в систему освіти, певним окремим сегментом навчання, виховання, методичного чи інформаційного забезпечення, організації чи адміністрування. Інновації в освіті завжди несуть потенціал системного оновлення, нехай вони навіть ставлять за мету розвиток особистісних компетенцій суб'єктів навчання і виховання.

Новизна як головний індикатор інноваційного процесу в освіті $€$ важливим показником як на індивідуально-особистісному, так і на системно-суспільному рівні. Можна сказати, що за своєю сутністю освіта $є$ процесом оновлення як для особистості, так і для суспільства в цілому. У цьому контексті важливо звернути особливу увагу і провести детальний аналіз сутності інноваційних процесів в освіті як результату органічної взаємодії її (освіти) основних суб'єктів. Суб'єктний вимір освітнього поля в рамках сучасного освітнього дискурсу $€$ одним 3 пріоритетних напрямків дослідження. При цьому суб'єктне значення інноваційної діяльності в освіті не просто не суперечить, але й підтримує високий рівень актуальності даних інновацій і для соціуму. Саме через те, що розвиток людини важливий сьогодні і для суспільства, людство отримує сьогодні нову гуманістичну перспективу, яка, здавалося, була повністю втрачена через розвиток споживацької цивілізації.

Саме освіта допомагає кожній людині вирватися з порочного кола споживацького життя і перетворитися на активного суб'єкта творчості, креативності та ініціативності. Фактично, інноваційна освіта перетворюється для людини на екзистенціальний простір свободи і відповідальності. «Суб'єкт в освітньому просторі набуває таких характеристик, як особиста відповідальність за свою освіту в умовах «інформаційного вибуху» і експансії мас-медіа; будує власну ідентичність в умовах «невизначеної», ігрової, віртуальної реальності; розширює діапазон особистісних виборів у сфері самовизначення і відповідальності за них. У такому розумінні суб'єкту в освітньому просторі притаманні свідома діяльність і свобода як найзагальніші аксіологічні домінанти його буття» [4, с. 97-98]. Інноваційна освіта здатна відіграти справді онтологічну роль в життєвій стратегії кожної людини. Це обов'язково треба враховувати, формулюючи в сучасному освітньому дискурсі парадигмальні основи розуміння сутності інноваційних процесів.

При цьому на особистісний та світоглядно-аксіологічний рівень людської життєдіяльності чиниться багатовимірний вплив з боку інноваційно-гуманістичної освіти. До того ж такий вплив 
не $є$ авторитарним, він не наполягає на певних цінностях чи моделі поведінки, а таким, що додатково сприяє самореалізації особистості в креативно-творчий спосіб. В нашій країні такі зміни все ще залишаються актуальними, адже наша система освіти ще не переведена повністю на суб'єкт-суб'єктні принципи інноваційно-демократичного, особистісно орієнтованого навчання. Перед українською освітянською спільнотою постає важливе завдання розробити засадничі принципи та реалізувати практичну стратегію масштабного інноваційного оновлення освіти. Підкреслюючи значення світоглядно-ціннісних та особистісно-культуротворчих компонентів, не можна залишати поза увагою і педагогічно-технологічні аспекти освітніх інновацій. Саме новітні інноваційні технології (як чисто педагогічні, так і інформаційні) дозволяють повноцінно реалізовувати суб'єктний потенціал творчості, креативності, ініціативи, пізнавальної та вольової активності. У цій точці і поєднуються інноваційна освіта та інноваційна особистість. Остання перетворюється на активно-творчого, креативно-конструюючого елемента першої. Інноваційна ж освіта, в свою чергу забезпечує максимально сприятливі умови для повноцінної самореалізації та саморозвитку інноваційної особистості. При чому вона може розвиватися виключно в гармонійному, демократичному, миролюбному, гуманістичному просторі суб'єктсуб'єктної взаємодії та педагогічної комунікації.

Сучасний стратегічний підхід у системі сучасного знання потребує створення та підтримки адекватної архітектоніки. Лінійний підхід не дуже виправдовував себе ще у часи класичного періоду розвитку науки, а тепер він не може забезпечити базову методологічну підтримку системи сучасних досліджень. У постнекласичному періоді наукового розвитку необхідним стає пріоритет визначення перспектив найближчого майбутнього в ситуації глобальних ризиків. Зазначена ситуація визначає спосіб засвоєння суспільством нових ідей, сприйняття та оцінки нестандартних думок, реакції на зміни зовнішнього середовища. Вагомим сегментом такої системи стає національний соціально-економічний процес, який виражає технологію та методологію існування сучасного знання, а головним аспектом такого процесу $є$ механізми формування, збереження та перетворення технологій матеріального виробництва, які забезпечують певний спосіб існування нації. На сучасному етапі розвитку інтеграція як індивідуальної так і загальної тенденції структурованого суспільства виражається у створенні синергійного ефекту, який може стати передумовою досягнення бажаного результату.

Отже, ефективний результат створення нової організаційної системи зростає, якщо синергійний ефект від конфігурованого цілого більше ніж ефект від поєднання певної суми елементів або в результаті створення відповідної комбінації одночасно функціонуючих окремо, але взаємопов'язаних між собою складових системи. Такий процес можливий тільки на базі введення ефективної системи моделювання економічної освіти в основу якого покладене отримання ефекту «синергії» та практичні результати розробки програмних продуктів за сучасними інформаційними технологіями. Зрозуміло, що в контексті даного дослідження принцип синергізму слід розглядати як методику та методологію моделювання стратегії економічної освіти.

Існує думка про те, що стратегічний процес повинен аналізуватися як взаємодія систем, при чому в деяких випадках занадто політизованих. Вважається, що цілі та напрямки руху діяльності суспільних інститутів та організацій залежить від владної потреби ії членів. Окремо треба звернути увагу на сферу економіки в Україні останніх років, у який адаптування економічних змін відбувається виключно шляхом пристосування до політичних реформ, відповідно така ситуація впливає на функціонуванні всієї освітньої системи.

Аналізуючи дослідження провідних вітчизняних і зарубіжних науковців, було з'ясовано, що невирішеними залишились питання, які розкривають сутність стратегії синергізму як однієї 3 потенціалоутворюючих освітніх стратегій в основу якої покладено використання ефекту конфрігурування ключових компетенції у сфері освітньо-економічного процесу. Відповідно логічним продовженням дисертаційного дослідження стає спроба проаналізувати процес формування та реалізації стратегії системи вищої освіти в національному освітньоекономічному просторі за допомогою використання конфігурованого синергійного ефекту. Дослідження спрямовується на виявлення основних характеристик даного поняття та оцінку резонансу застосування елементів «синергії» на «виробничих одиницях» системи вищої освіти, що сприяє можливості максимізувати синергійний ефект управління як на рівні аналітики, так і в практичному плані використання такої формули конфігурованого синергійного ефекту освітньо- 
економічного процесу. В результаті, по-перше, надається поштовх активізації внутрішніх ресурсів системи вищої економічної освіти, а по-друге, з'являється можливість упорядкування ресурсних складових двох автономних систем як освітньої, так і економічної, що створює теоретичні умови появи відповідних програмних продуктів для постійного практичного використання в системі управління.

Принцип синергізму повністю відкидає можливість механічного поєднання існуючих складових зазначених систем. Таке поєднання може відбутися тільки завдяки застосуванню оригінального конфігурованого синергійного ефекту національного освітньо-економічного процесу. Стосовно синергійного ефекту треба зазначити, якими б потенційно прогресивними не були його можливості та результати, він не може виявлятися сам по собі. Такий ефект потрібно свідомо планувати й організовувати, тому першочерговим завданням управління $є$ виявлення внутрішнього потенціалу самої системи та її ресурсної бази, результати дослідження якої й стануть джерелом отримання синергетичної переваги.

Теоретичне обґрунтування конфігурованого синергійного ефекту національного освітньоекономічного процесу включає аналіз у розгорнутому вигляді зазначених складових ключових компетенцій полісистеми, механізм їх взаємодії та відповідний суспільний результат його практичного використання. Крім того, особливої уваги заслуговує виявлення теоретичних засобів необхідних для пристосування до вимог турбулентного як економічного, так і освітнього зовнішнього середовища та їх спрямування у бажанні отримати «синергію» від гармонізації комбінування антонімічних категорій. Для пояснення зазначеної тези, можна звернутися до думки С. Кримського стосовно питань методологічної свідомості, метода та стиля мислення: «Безкінечність категорій має вигляд діяльнісного освоєння всіх можливостей змісту динаміки думки. Категорії розширено відтворюються в духовному виробництві людських цивілізацій і потребують внаслідок своєї всезагальності необмеженого культурно-історичного здійснення» [1, с. 116]. Історичні події на Україні останніх років підтверджують стохастичний характер фрункціонування її політичної, економічної, освітньої систем, які вже не можна аналізуватися виключно за допомогою метода причинно-наслідкового зв'язку, котрий є панівним для сталих, динамічних систем.

Отже, такому стану відповідає конкурентний процес на ринку, де інтереси двох сторін змінює вплив третього фрактору або сторони, що призводить до зміни стану рівноваги. У певний момент, що також має випадковий характер, визначається критична точка, яку І. Пригожин назвав біфуркацією та з'являється сукупність альтернатив, кожна 3 яких має можливість стати реальністю. Проблема полягає у тому, як із всієї сукупності альтернатив вибрати одну максимально вірну та найбільш результативну - це є головним завданням в управлінні будьякою системою.

Синергетика забезпечує процес самомодуляції й якщо вона відбуватися не буде, то створюються умови для знищення будь-якої системи, наприклад, певна держава може зникнути внаслідок зовнішніх завоювання, внаслідок саморуйнування або внаслідок політичних революцій. Причому як під час завоювання, так і під час революцій заміна чи руйнування держави обґрунтовується моральними, економічними та правовими засобами, серед яких основним $\epsilon$ «забезпечення справедливості». У зв'язку з цим важливо звернути увагу та обов'язково враховувати в дослідженнях у галузі економічної освіти природу державного закону, як міри справедливості та здійснювати аналіз багатьох її недоліків з точки зору парадоксів «державної справедливості».

Таким чином, стохастична система соціально-економічних процесів досліджується науковотехнологічним інструментарієм теорії вірогідності, у той час як динамічна система спрацьовує у період рівноважного стану невизначеності, характеризується причинно-наслідковим зв'язком процес їх замикання утворює емерджентний стан системи, який має додаткові характеристики. Відповідно, якщо система змішана та незворотна, а в такому стані знаходиться будь-яка освітня, політична або економічна система, то описати незворотність процесів означає пояснити як утворюється нові «правила гри», а це надає можливість з'ясувати процес фрормування рішень та концепцій державного розвитку будь-якого напряму.

Важливим додатковим моментом у створенні такої ключової компетенції як науковотехнологічна синергія соціально-економічних процесів $€$ те, що в системі економічного знання об'ємним сегментом є інфрормаційно-символічні процеси, наприклад, обіг грошей, фрормування 
ринкової ціни, перевтілення капіталу в різні форми, ту саму вартість товару можна виявити лише у процесі обміну на інший товар та безліч інших процесів, без яких господарювання стає неможливим.

Отже, саме інформаційно-символічні процеси пов'язують розрізнені трудові процеси й операції у єдине ціле, створюючи тим самим опосередковану систему обміну, тому можна стверджувати, що пріоритетною зоною синергії в неоекономіці стають саме неречові елементи.

Такий підхід дає можливість зрозуміти проблеми сучасного суспільства кожної нації, в якому люди одного покоління можуть використовувати досягнення культури, економіки, наукові ідеї різних епох. Проте ні марксистська концепція суспільно-економічних фрормацій, ні позитивістська культурологічна концепція суспільства, а ні постмодерністські орієнтації, які на даний момент не змогли позбавили культуру її традиційного розуміння не дають вичерпного розуміння економічного життя суспільства та самі існують немов би на периферії традиційно представленої духовності. У такому кліматі споконвічного економічного «ризику», у стані нестабільних орієнтацій наша людина змушена постійно вибирати себе, самовизначатися та самоідентифікуватися в системі виробничих відносин.

Складність проблеми полягає у тому, що в соціально-гуманітарних системах, на відміну від природних, самоорганізація доповнюється організацією, оскільки в суспільстві діють люди, які наділені свідомістю, мають певні цілі, мотивацію їх досягнень, ціннісні орієнтири тощо. У зв'язку з цим взаємодія самоорганізації й організації, необхідного та випадкового складають основу перетворень будь-яких соціальних систем. Такий ефект «нерівномірності» найбільше відповідає системі освіти, ніж іншим сферам діяльності, тобто саме освіта або відсутність освіченості $€$ причинами таких явищ і процесів, що проектують ситуацію нерівномірності в інших сфрерах, безпосередньо це відчувається в політиці, економіці та медицині: «У стохастичній системі не можна визначити де є причина, а де наслідки, ми не можемо з'ясувати її структурність та упорядкованість. Така система поводить себе інакше: функціонує за допомогою флуктуацій, часто залежить від несуттєвих, на перший погляд, обставин. Стратегічною тезою постнеокласичного періоду є твердження про можливість перескакування з однієї траєкторії на іншу і втрату системної пам'яті. У багатовимірній моделі взаємодій, де беруть участь не дві, а більше сторін, виникає так званий «турбулентний простір» [5, с. 219]. У зв'язку з цим зацікавленим у вирішенні протиріч між реальним станом речей і бажаним в економіці та інших сорерах необхідно, перш за все, звернути увагу на можливості багатофракторної освіти, на її оптимізуючу та соціально регулюючу функції в різних сферах життєдіяльності суспільства.

Продовжуючи розвідку значення синергійного ефекту в системі соціально-економічного процесу та найбільш вагомих його складових, звернемо увагу на той фракт, що неможливість передбачення подій деякою мірою компенсується отриманням необхідної попередньої інформації. У цифрову епоху, коли інформація на «вагу золота», фундаментальні підходи до управління, у тому числі й в системі вищої освіти, є дещо сумнівними. Прогалини, які виникають в процесі управління, можна заповнити за допомогою інформаційної нукліаційної функції. Вона розуміється як процес первинного встановлення інформаційної тези в деякій кінцевій області, а потім за визначеною схемою вона розповсюджується, «заповнюючи» весь простір. У даному контексті наповнювачем буде інформаційний або компенсуючий синергійний ефект, що виникає в процесі управління освітньою системою й який ми маємо отримати збираючи та аналізуючи внутрішні та зовнішні інформаційні потоки.

Отже, саме створення конфігурованого синергійного ефекту завдяки новому комплексу методологічних засобів, відповідної системи ключових компетенцій та механізму їх поєднання сприяє формуванню нових організаційних форм, які досить стабільні, погоджені між собою та навколишнім оточенням за рядом ознак і забезпечують філософсько-методологічні засади дослідження функціонування національного освітньо-економічного процесу в Україні. Однак обов'язково треба враховувати можливість виникнення асиметрії інформації та інших фракторів, які створюють умови негативного прояву синергійного ефекту, тому дана проблематика потребує подальшого окремого дослідження зазначено феномену та його практичного застосування. У свою чергу, нова конфігурація сучасної системи знань - це злагоджене поєднання можливостей, компетенцій, як матеріальних, так і невидимих ресурсів, цінностей та прагнень ефективної результативності, яких вона намагається досягти в майбутньому за рахунок синергійних конфігурацій. У таких умовах повинна приділятися особлива увага 
створенню міждисциплінарних проектів, що дозволить прискорити час появи нових сфер діяльності майбутнього, а це у свою чергу допоможе задовольнити вимогливість запитів сучасного виробництва та всієї соціально-економічної системи.

Висновки. Проаналізувавши конфігурований синергетичний ефект інноваційного процесу формування сучасної системи знань в Україні як складний соціальний акт, що охоплює аналіз таких ключових компетенцій, як інтегральна інформаційно-технологічна модель досліджень, науково-педагогічні технології навчання, особистісно-професійна компетентність самого фахівця та новітні механізми, методи і засоби системи управління сучасної науково-дослідницької сорери, було представлено механізм їхньої взаємодії з обов'язковим урахуванням особливостей національно-смислового поля та типу культури відповідного суспільного виробництва та можливості отримання суспільного результату від його практичного використання. нова конфігурація сучасної системи знань - це злагоджене поєднання можливостей, компетенцій, як матеріальних, так і невидимих ресурсів, цінностей та прагнень ефективної результативності, яких вона намагається досягти в майбутньому за рахунок синергійних конфігурацій. У таких умовах повинна приділятися особлива увага створенню міждисциплінарних проектів, що дозволить прискорити час появи нових сорер діяльності майбутнього, а це у свою чергу допоможе задовольнити вимогливість запитів сучасного виробництва та всієї соціальноекономічної системи. Нами було запропоновано розгорнутий аналіз оригінальних нововведень у сфрері формування сучасної системи знань та зазначено, що складний характер сучасних інновацій вимагає нової структурної конфігурації, яка поєднує змінні складники самого механізму дослідження, шо базуються на компетенціях, а не на можливостях владних організацій і тоталітарних фрормах управління.

\section{Література}

1. Біла книга національної освіти України / Т. Ф. Алєксєєнко, В. М. Аніщенко, В. Г. Кремень [та ін.]; за заг. ред. В. Г. Кременя. - Київ: Інфрормаційні системи, 2010. - 340 с.

2. Герасимова, Е. М. Економічне знання у дискурсі становлення глобалізованого світу: соціально-фрілософський аналіз: моногр. / Е. М. Герасимова. - Чернігів : ЧДІЕУ, 2008. - 336 с.

3. Грубіч, Д. Ю. Педагогічні інновації в освіті: поняття та сутність / Д. Ю. Грубіч // Педагогіка та психологія. - 2011. - Вип. 40 (1). - С. 34-39.

4. Кримський, С. Б. Запити фрілософських смислів / С. Б. Кримський. - Київ: Вид. ПАРАПАН, 2003. - 240 с.

5. Панфілова, Я. О. Суб'єкт в освіті: класична та некласична парадигми / Я. О. Панфрілова // Вісник Національного університету "Юридична академія України імені Ярослава Мудрого". Серія : Філософрія, філософрія права, політологія, соціологія. - 2014. - № 4. - С. 91-99.

6. Ратовська С. В. Теоретичні засади впровадження освітніх інновацій у вищих педагогічних навчальних закладах / С. В. Ратовська // Проблеми сучасної педагогічної освіти. Педагогіка і психологія. - 2013. - Вип. 38 (2). - С. 235-246.

\section{References}

1. Alieksieienko, T. F., Anishchenko, V. M., Kremen, V. H. (2010). Bila knyha natsionalnoi osvity Ukrainy [White Book of National Education of Ukraine]. V. H. Kremen (Eds.). Kyiv: Informatsiini systemy [in Ukrainian].

2. Gerasymova, E. M. (2008). Ekonomichne znannia u dyskursi stanovlennia hlobalizovanoho svitu: sotsialno-filosofskyi analiz [Economic knowledge in the discourse of the globalized world: socio-philosophical analysis]. Chernihiv: ChDIEU [in Ukrainian].

3. Hrubich, D. Yu. (2011). Pedahohichni innovatsii $v$ osviti: poniattia ta sutnist [Pedagogical innovations in education: concept and essence]. Pedahohika ta psykholohiia - Pedagogy and psychology, 40 (1), 34-39 [in Ukrainian].

4. Krymskyi, S. B. (2003). Zapyty filosofskykh smysliv [Requests of philosophical meanings]. Kyiv: Vyd. PARAPAN [in Ukrainian]

5. Panfilova, Ya. O. (2014). Subiekt $v$ osviti: klasychna ta neklasychna paradyhmy [Subject in education: classical and non-classical paradigms]. Visnyk Natsionalnoho universytetu «Yurydychna akademiia Ukrainy imeni Yaroslava Mudroho». Ser.: Filosofiia, filosofiia prava, politolohiia, sotsiolohiia - Bulletin of the National University "Yaroslav the Wise Law Academy of Ukraine". Ser.: Philosophy, philosophy of law, political science, sociology, 4(23), 91-99 [in Ukrainian].

6. Ratovska, S. V. (2013). Teoretychni zasady vprovadzhennia osvitnikh innovatsii u vyshchykh pedahohichnykh navchalnykh zakladakh [Theoretical principles of implementation of educational innovations in higher pedagogical

educational institutions]. Problemy suchasnoi pedahohichnoi osvity - Problems of modern pedagogical education, 38 (2), 235-246 [in Ukrainian].

Надійшла 11.10.2019

Бібліографічний опис для цитування:

Лукашук, М. А. Соціальний досвід формування інноваційної конфігурації сучасних знань / М. А. Лукашук // Проблеми соціальної роботи: філософія, психологія, соціологія. - 2019. - № 2 (14). - С. 100-107. 